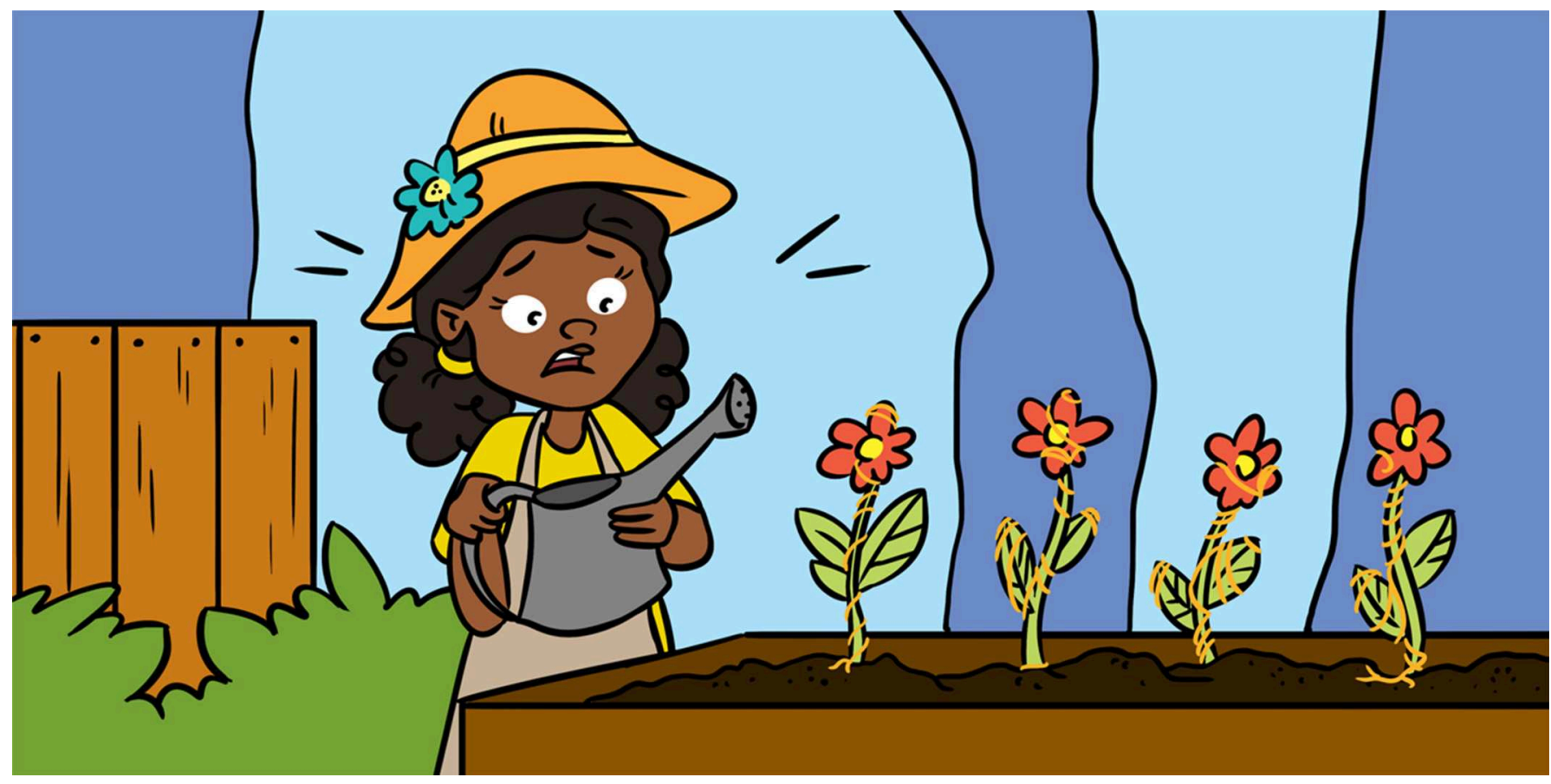

\title{
CHEATING BEATS COMPETING, FOR PARASITIC CUSCUTA PLANTS
}

\section{Johnathan J. Dalzell *}

School of Biological Sciences, Institute for Global Food Security, Queen's University Belfast, Belfast, United Kingdom

YOUNG REVIEWER:

SHASHI

PREETHAM

AGE: 12
Plants must compete with each other for access to resources like water, nutrients, and light, which allow them to grow and reproduce. Competition for these resources takes place both above and below the soil. Plant roots absorb water and nutrients from the soil and physically anchor the plant so that it can grow tall. The plant must then try to outgrow other competitors to gain better access to sunlight, which it uses to create energy through photosynthesis. Rather than compete fairly, some plants will instead steal these resources from other plants. Plants that cheat in this way are called parasites. Many parasitic plants have become such specialist cheats that they do not waste time or energy on developing their own roots or leaves, or on using photosynthesis to make their own energy. Cuscuta plants are parasites that are commonly known as "dodders." Scientists are trying to better understand these parasites and develop new ways to prevent them stealing from other plants that we need for food or fiber. 


\section{PARASITE}

An organism that lives in or on another organism (the host), to its own benefit, and at a cost to the host.

\section{HOST}

An organism that is a source of water, nutrients and other resources for a parasite.

\section{PHYTOCHROME}

A protein that plants use to sense and respond to light.

\section{THIGMOMOR-}

\section{PHOGENESIS}

A response of plants to touch, which involves a change in growth pattern.

\section{HAUSTORIUM}

The invasive structure used by parasitic plants to invade and steal resource from a host plant.

\section{THE LIFE OF A PROFESSIONAL CHEAT}

\section{Finding a Host Plant}

Cuscuta parasites germinate from seeds, just like many other plants. They grow a very small root that helps hold them to the ground as the shoot grows in search of a nearby host plant. The parasite seedling will use a number of senses to find the host, including "smell", "sight", and "touch" [1]. Although the parasite does not have a nose as we do, it has specialized proteins within the growing shoot that it uses to identify and react to smells of a suitable host plant. When the parasite identifies an attractive smell, it will direct growth toward the source of that smell [2].

As the parasitic seedling gets closer to the host plant, it will experience the shading effect of the host plant's leaves blocking out sunlight. Whilst the parasitic plant does not have eyes, it does have specialized proteins called phytochromes that allow the plant to "see" different types of light, and to determine if it is in full sunlight or in shaded conditions [3]. This helps the parasite to prepare for host contact and invasion.

Finally, the parasite will make contact with a host plant and experience "touch." Many plants respond to touch. For most plants, however, touch is associated with danger. Touch could indicate to a plant that insects are landing on its leaves and trying to eat them. In this case, plants use touch to stop growth and instead spend their valuable energy resources on defense. These plants make a range of toxic chemicals that will stop insects from feeding on them. Some plants also use touch to trigger a strengthening of the leaf cell walls, making it harder for the insects to eat them. For Cuscuta parasites, touch is a positive stimulus, telling the parasite that it has made contact with a potential host plant. In response to touch, the parasite will use a complex response called thigmomorphogenesis (pronounced "thig-more-fo-genesis") to change its growth pattern and will wind around the host plant stem (Figure 1).

\section{Invading a Host Plant}

When the Cuscuta parasite finds and makes contact with a host plant, it will release a biological glue that holds it firmly against the host plant stem. It will then form a special invasion structure called the haustorium (pronounced "haw-stawr-ee-uh-m"). The haurstorium develops new shoots that will mechanically invade the host plant stem, with the help of various proteins that it will release to break down and degrade the host plant cell walls (Figure 2). When the haustorium has successfully penetrated the host plant stem, it will seek the cells that plants use to transport water and nutrients, called xylem (pronounced "zi-lem") and phloem (pronounced "flow-em") cells. The parasite haustorium fuses to the xylem and phloem cells and will extract water and nutrients to fuel the parasite's growth, flowering, and 


\section{Figure 1}

The Cuscuta parasite finds a host plant by "smell", "touch", and "sight." It winds around the host stem to get a good grip, which allows it to invade and steal water and nutrients from the host plant. It will later grow away from the host plant stem, looking for other plants to steal from.

\section{Figure 2}

A microscopic cross-section of a Cuscuta parasite (P) invading a host plant (H). This shows the haustorium, which the parasite uses to punch a hole in the host plant stem and steal host resources. The parasite does this using mechanical force and by releasing proteins that break down the host plant cell walls

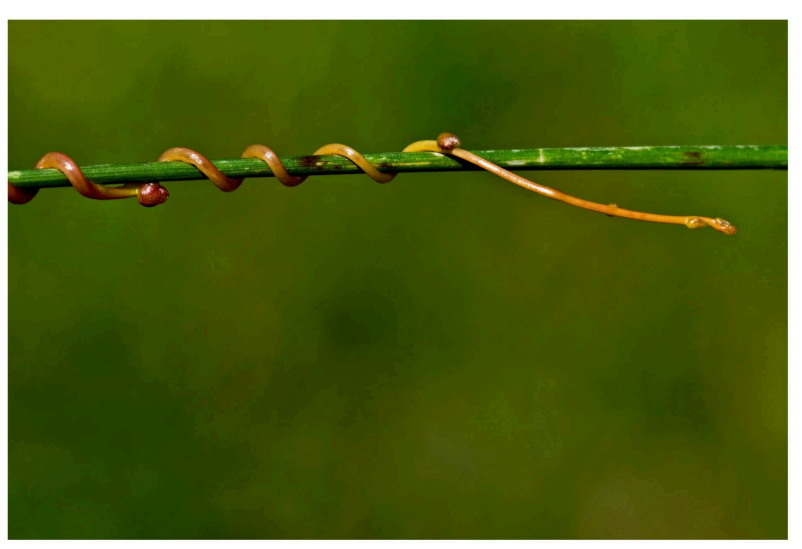

Figure 1

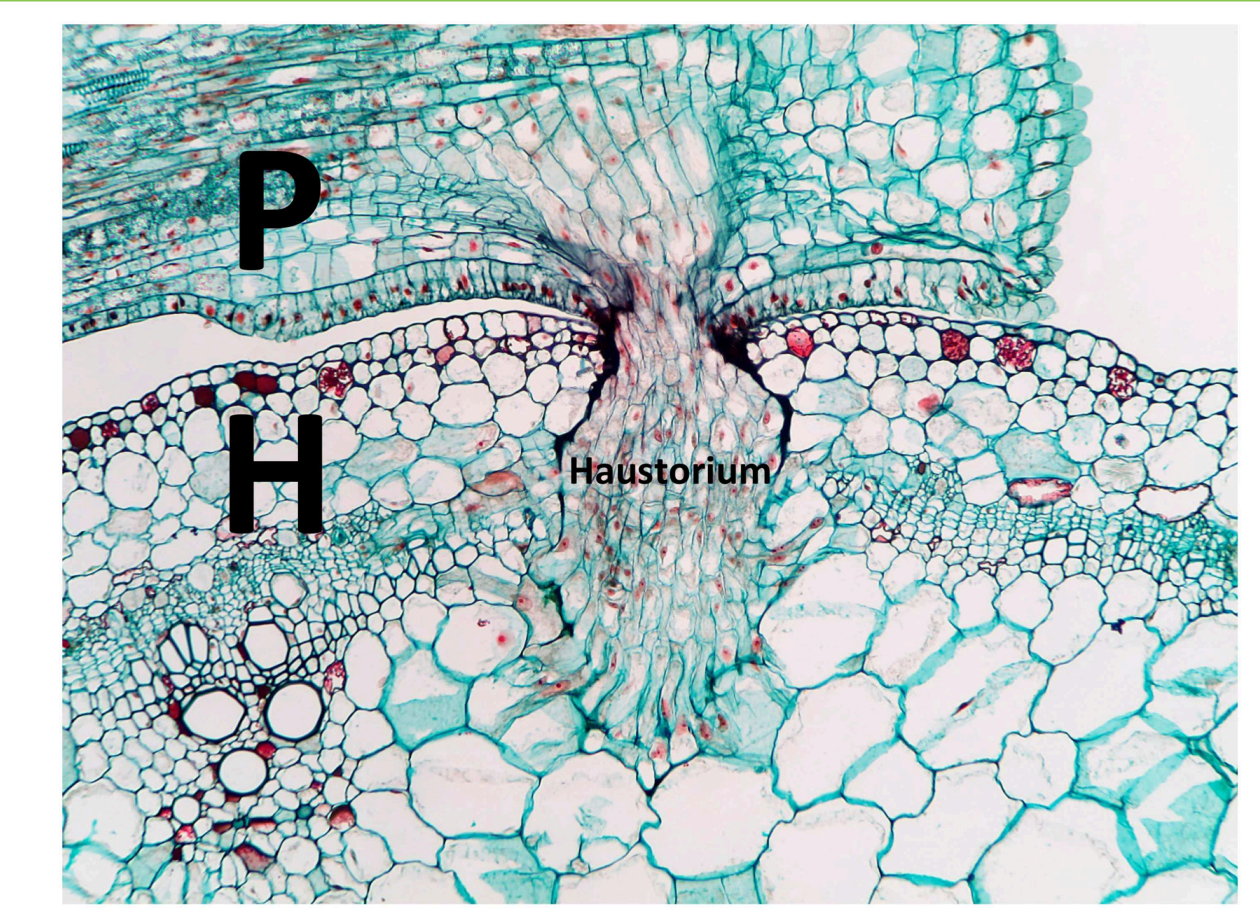

Figure 2

the production of seeds. This interaction benefits the parasite, but is bad for the host plant, which will grow less and produce fewer seeds as a result of the parasite.

Once the parasite has invaded a host plant, it starts to grow new shoots. These secondary shoots will attempt to establish additional connections with the same host plant or other nearby plants. More invasion sites mean more food for the parasite and less chance of failure. We assume that the parasite uses many of the same senses to establish additional host interactions; however, the parasite will also try to invade non-host objects, like bamboo canes, which do not provide it with any food. We do not really understand why this happens, but it may be that, once a seedling has invaded a host plant, it assumes 


\section{APOPTOSIS}

A process that allows organisms to purposefully kill some of their own cells.

\section{BIOTROPHIC}

Refers to a parasite or pathogen that can only gain resource from live host cells. that any other touch stimulus represents the same plant or a nearby host plant.

\section{Subduing and Compensating the Host Plant}

When the parasitic Cuscuta plant invades the host plant, the parasite and host will battle each other for control. The host plant will attempt to prevent the parasite from invading by strengthening its cell walls and releasing toxic compounds. If none of those strategies work, the host plant will attempt to kill the cells around the parasite, in a process called apoptosis (pronounced "a-pop-toe-sis"). Cuscuta parasites, like many other parasites, are biotrophic, meaning that they can only steal resources from live host cells. If the host plant kills the cells around the parasite haustorium, the parasite will not be able to steal the host's resources. At the same time, the parasite will release a range of chemicals and molecules that will manipulate the host and prevent it from mounting a normal defense response against the parasite [4].

Although parasites are, by their very nature, "selfish" in their actions, under certain circumstances Cuscuta parasites will help to protect their host plants-teamwork makes the dream work! If a Cuscuta parasite has invaded two different plants and one of those host plants is being damaged by insect pests, the parasite will tell the other host plant and help it to defend itself against the insect [5]. This obviously benefits the host plant, but it also benefits the parasite, because the parasite does not have to compete with insect pests for the same limited host resources.

\section{THE PROBLEM WITH CUSCUTA...}

\section{The Negative Impact of Cuscuta Parasites}

By stealing water and nutrient resources, Cuscuta parasites can lower the yields of crop plants that we rely on for food and other materials (Figure 3). As the global population increases, we need to find ways to grow more food from less land-a problem that we call sustainable intensification of agriculture. Preventing the parasitism of crops is one approach to achieving this goal of growing more food, but we need to know much more about the biology of these parasites to stop them effectively.

Recently, scientists have sequenced the genome of two Cuscuta species [6,7], which will help us to understand exactly how these parasites find, invade, and manipulate host plants. Using a range of research techniques, we can now start to develop new ways of preventing the loss of crop yield to these parasites, which will help to improve global food security. 
Figure 3

Cuscuta parasites smother host plants and reduce their ability to grow. This has a negative impact on agriculture and ultimately on our ability to feed the increasing number of people on the planet

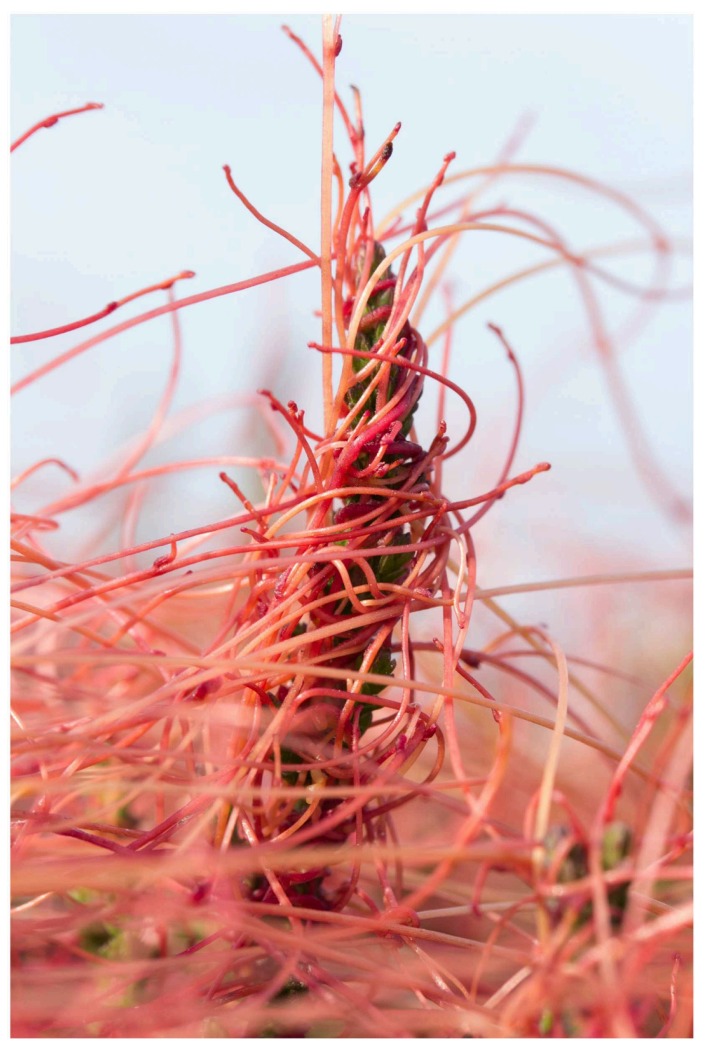

Figure 3

\section{CONCLUSION}

Cuscuta parasites are professional cheats, stealing nutrients and water from other plants. This reduces the quality and yield of important crops, and makes it more difficult to feed the planet. Although we are beginning to understand how these parasites find and manipulate host plants, there is still much that we do not yet understand. Now that the genome of several Cuscuta parasites has been sequenced, it will help us to develop new ways of interfering with their biology, and preventing crop losses.

\section{REFERENCES}

1. Chamovitz, D. 2017. What a Plant Knows: Updated and Expanded Version. Macmillan USA.

2. Runyon, J. B., Mescher, M. C., and Moraes, C. D. 2006. Volatile chemical cues guide host location and host selection by parasitic plants. Science 313:1964-7. doi: 10.1126/science.1131371

3. Benvenuti, S., Dinelli, G., Bonetti, A., and Catizone, P. 2005. Germination ecology, emergence and host detection in Cuscuta campestris. Weed Res. 45:270-8. doi: $10.1111 / \mathrm{j} .1365-3180.2005 .00460 . x$

4. Shahid, S., Kim, G., Johnson, N. R., Wafula, E., Wang, F., Coruh, C., et al. 2018. MicroRNAs from the parasitic plant Cuscuta campestris target host messenger RNAs. Nature 553:82-5. doi: 10.1038/nature25027 
5. Hettenhausen, C., Li, J., Zhuang, H., Sun, H., Xu, Y., Qi, J., et al. 2017. Stem parasitic plant Cuscuta australis (dodder) transfers herbivory-induced signals among plants. Proc. Natl. Acad. Sci. U.S.A. 2017:201704536. doi: 10.1073/pnas.1704536114

6. Vogel, A., Schwacke, R., Denton, A. K., Usadel, B., Hollmann, J., Fischer, K., et al. 2018. Footprints of parasitism in the genome of the parasitic flowering plant Cuscuta campestris. Nat. Commun. 9:2515. doi: 10.1038/s41467-018-04344-z

7. Sun, G., Xu, Y., Liu, H., Sun, T., Zhang, J., Hettenhausen, C., et al. 2018. Large-scale gene losses underlie the genome evolution of parasitic plant Cuscuta australis. Nat. Commun. 9:2683. doi: 10.1038/s41467-018-04721-8

SUBMITTED: 19 December 2018; ACCEPTED: 13 May 2019; PUBLISHED ONLINE: 29 May 2019.

EDITED BY: Vishal Shah, West Chester University, United States

CITATION: Dalzell JJ (2019) Cheating Beats Competing, For Parasitic Cuscuta Plants. Front. Young Minds 7:74. doi: 10.3389/frym.2019.00074

CONFLICT OF INTEREST STATEMENT: The author declares that the research was conducted in the absence of any commercial or financial relationships that could be construed as a potential conflict of interest.

COPYRIGHT () 2019 Dalzell. This is an open-access article distributed under the terms of the Creative Commons Attribution License (CC BY). The use, distribution or reproduction in other forums is permitted, provided the original author(s) and the copyright owner(s) are credited and that the original publication in this journal is cited, in accordance with accepted academic practice. No use, distribution or reproduction is permitted which does not comply with these terms.

\section{YOUNG REVIEWER}

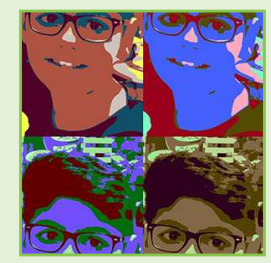

\section{SHASHIPREETHAM, AGE: 12}

Hello, my name is Shashi, I am 12 years old and I go to Penglais School. I enjoy playing football and basketball. My favorite subjects are Maths and Computers. I am currently studying year 7. I am a four times Guinness World Records holder in a game called Rocket League and my name is in 2018 Guinness World Record Gamers Edition.

\section{AUTHOR}

\section{JOHNATHAN J. DALZELL}

Johnathan is a senior lecturer in molecular biology and parasitology at Queen's University Belfast. He is fascinated by the biology and behavior of parasitic nematodes and plants. The goal of his research team is to develop new approaches to stop parasites infecting and manipulating crop plants. *j.dalzell@qub.ac.uk 